\title{
Perspektif Hukum Islam Terhadap Surat Keterangan Hibah Atas Harta Bersama Kepada Anak Angkat Yang Dilakukan Tanpa Persetujuan Istri
}

\author{
Intan Bulandari Nasution*, Enny Mirfa \\ Fakultas Hukum, Universitas Samudra, Indonesia \\ *Corresponding author: intanbulandarinasution@unsam.ac.id
}

\begin{abstract}
ABSTRAK
Penelitian ini bertujuan untuk mengetahui pandangan hukum Islam mengenai hibah atas harta bersama kepada anak angkat yang dibuat tanpa persetujuan istri, yang dilakukan dengan menuangkannya ke dalam bentuk surat keterangan hibah. Hukum Islam tidak menjelaskan secara spesifik mengenai tata cara pemberian hibah apakah harus tertulis atau tidak. Akan tetapi telah diatur mengenai rukun yang harus dipenuhi agar hibah menjadi sah menurut hukum Islam. Adapun metode penelitian yang digunakan adalah dengan menggunakan penelitian yuridis normatif. Sedangkan metode pendekatan yang dipakai dalam penelitian ini adalah deskriptif analisis, maksudnya dari penelitian ini diharapkan diperoleh gambaran secara rinci dan sistematis tentang permasalahan yang akan diteliti. Berdasarkan penelitian ini, didapatkan simpulan bahwa ketentuan yang telah diatur dalam Kompilasi Hukum Islam, surat keterangan hibah yang objek hibahnya adalah harta bersama, yang dibuat tanpa persetujuan istri telah melanggar ketentuan pasal 92 Kompilasi Hukum Islam. Akibat hukumnya hibah menjadi batal, dan surat keterangan hibah tidak berkekuatan hukum.
\end{abstract}

Kata Kunci : Hibah, Harta Bersama, Anak Angkat, dan Kompilasi Hukum Islam

\section{ABSTRACT}

This study aims to determine the perspective of Islamic Laws regarding the grant from joint property to an adopted child which is made unbeknownst of the wife, which is done into the notification letter. Islamic Laws does not specifically regulate the procedures of granting whether it must be written or not. However, Islamic Laws has been regulated about the principles of grant that has to be done by fulfilling principles, so that the grant to be valid. The research applies normative juridical method. It uses descriptive analysis approach, meaning that this research is expected to provide detailed and systematic description about the problems studied. The results of the research demonstrate that in Compilation of Islamic Laws, notification letter about grant from joint property, made without wife's consent has violated the provisions in Article 92 of Compilation of Islamic Laws. The legal consequence for the grant is cancelled, and for the notification letter made without the wife's consent is that the letter becomes null.

Keywords: Grant, Joint Property, Adopted Child, Compilations of Islamic Laws

\section{PENDAHULUAN}

Pengangkatan anak telah diatur secara tegas ke dalam undang-undang positif di Indonesia. Salah satunya di dalam Undang-undang Nomor 35 tahun 2014 tentang perubahan atas Undangundang Nomor 23 tahun 2002 tentang Perlindungan Anak yang disebutkan di dalam pasal 1 ayat (9), yaitu, "anak angkat adalah anak yang haknya dialihkan dari lingkungan kekuasaan keluarga orang tua, wali yang sah, atau orang lain yang bertanggung jawab atas perawatan, 
pendidikan,dan membesarkan anak tersebut, ke dalam lingkungan keluarga orang tua angkatnya berdasarkan putusan atau penetapan pengadilan".

Pengangkatan anak sebelumnya telah dikenal di kalangan Arab sebelum Islam (masa jahiliyah) dengan istilah At-tabanni dan sudah ditradisikan turun temurun. Pengangkatan anak dengan istilah Arab tabanni atau tabanni ath-thifl yaitu menjadikan seseorang sebagai anak. AlQuran menyebut pengangkatan anak dengan da'iyyun, yaitu menghubungkan asal usul kepada seseorang yang bukan ayah kandungnya. ${ }^{1}$ Islam memberikan batasan-batasan tertentu terkait dengan pengangkatan anak, salah satunya adalah terkait hal waris mewarisi. Oleh karenanya, banyak orang tua angkat yang memberikan harta kepada anak angkatnya melalui hibah.

Pada kamus al-Munawir kata hibah merupakan bentuk masdar dari kata wahaba yang berarti pemberian. Secara istilah, hibah adalah suatu pemberian yang bersifat sukarela, tanpa mengharapkan adanya kontraprestasi dari pihak penerima pemberian, dan pemberian itu dilangsungkan pada saat si pemberi masih hidup. ${ }^{2}$ Hibah mutlak tidak menghendaki imbalan, baik yang semisal, atau yang lebih rendah, atau yang lebih tinggi darinya.

Permasalahan yang timbul kemudian adalah apabila harta yang dihibahkan sebagai sebuah hadiah, merupakan harta bersama, yang dilakukan tanpa sepengetahuan pasangannya baik suami maupun istri. Berdasarkan uraian tersebut diatas, maka permasalahan yang dapat diangkat, yaitu akibat hukum surat keterangan hibah atas harta bersama kepada anak angkat yang dibuat tanpa persetujuan istri ditinjau dari pandangan hukum Islam.

\section{KAJIAN PUSTAKA}

\section{Hibah}

Menurut Eman Suparman (2005), hibah adalah pemberian yang dilakukan oleh seseorang kepada pihak lain yang dilakukan ketika masih hidup dan pelaksanaan pembagiannya biasanya dilakukan pada waktu penghibah masih hidup juga. Biasanya pemberian pemberian tersebut tidak akan pernah dicela oleh sanak keluarga yang tidak menerima pemberian itu, oleh kerena pada dasarnya seseorang pemilik harta kekayaan berhak dan leluasa untuk memberikan harta bendanya kepada siapa pun. Sementara itu, menurut Hasballah Thaib (1999), Hibah adalah aqad yang berarti pemberian harta milik seseorang kepada orang lain sewaktu ia masih hidup, tanpa adanya imbalan.

\section{Harta Bersama}

Pengertian mengenai harta bersama telah pula dikemukakan oleh Ter Haar, yang mengatakan bahwa dalam arti umum harta bersama adalah barangbarang yang diperoleh suami isteri selama perkawinan. Menurut Ismail Muhammad Syah (1978), yang dimaksud dengan Harta Bersama atau Gono-gini atau Hareuta Sihareukat atau istilah-istilah lain lagi di berbagai daerah di Indonesia ialah harta kekayaan yang dihasilkan bersama oleh suami isteri selama mereka diikat oleh tali perkawinan, atau dengan perkataan lain, harta yang dihasilkan oleh perkongsian antara suami isteri.

\section{Anak Angkat}

Anak angkat menurut Undang-undang Nomor 35 tahun 2014 tentang perubahan atas Undangundang Nomor 23 tahun 2002 tentang Perlindungan Anak yang disebutkan di dalam pasal 1 ayat (9), yaitu: "anak angkat adalah anak yang haknya dialihkan dari lingkungan kekuasaan

\footnotetext{
${ }^{1}$ Fahmi Al Amruzi, Rekonstruksi Wasiat Wajibah dalam Kompilasi Hukum Islam, (Yogyakarta: Aswaja Pressindo, 2014 ), Hal 82.

${ }^{2}$ Mardani, Hukum Kewarisan Islam di Indonesia, (Jakarta: PT RajaGrafindo Perkasa, 2014), Hal 125.
} 
keluarga orang tua, wali yang sah, atau orang lain yang bertanggung jawab atas perawatan, pendidikan, dan membesarkan anak tersebut, ke dalam lingkungan keluarga orang tua angkatnya berdasarkan putusan atau penetapan pengadilan".

Selain itu, Arif gosita (1989), menyatakan bahwa pengertian pengangkatan anak atau adopsi adalah bahwa "pengangkatan anak (adopsi) adalah suatu tindakan mengambil anak orang lain untuk dipelihara dan diperlakukan sebagai anak turunannya sendiri, berdasarkan ketentuan-ketentuan yang disepakati dan sah menurut hukum yang berlaku di masyarakat yang bersangkutan. Sementara itu dalam Alquran menyebut pengangkatan anak dengan da'iyyun, yaitu menghubungkan asal usul kepada seseorang yang bukan ayah kandungnya.

\section{Kompilasi Hukum Islam}

Dalam bukunya, Abdurrahman (2002) menyatakan Pengertian Kompilasi Hukum Islam secara etimologis ialah kumpulan/ himpunan yang tersusun secara teratur. Sedangkan secara terminologi kompilasi diambil dari compilation (inggris) atau compilatie (belanda) yang diambil dari kata compilare, artinya mengumpulkan bersama-sama, seperti mengumpulkan peraturan-peraturan yang tersebar dimana-mana, istilah ini kemudian dipergunakan dalam bahasa indonesia kompilasi, sebagai terjemahan lansung.

Sekumpulan materi hukum Islam yang ditulis pasal demi pasal, berjumlah 229 pasal, terdiri atas kelompok materi hukum yaitu hukum perkawinan, ( 170 pasal ) hukum kewarisan termasuk wasiat dan hiba ( 44 pasal) dan hukum perwakafan ( 14 pasal ) ditambah satu pasal ketentuan penutup yang berlaku untuk ketiga kelompok hukum tersebut.

\section{METODE PENELITIAN}

Penelitian ini merupakan penelitian yuridis normatif dengan pendekatan deskriptif analisis, dengan menggunakan sumber data yaitu data sekunder yang terdiri dari bahan hukum primer, bahan hukum sekunder, dan bahan hukum tersier. Pengumpulan data dilakukan dengan studi kepustakaan, dan kesimpulan ditarik dengan metode deduktif.

\section{HASIL DAN PEMBAHASAN}

Suatu peristiwa dikategorikan sebagai peristiwa hukum ketika terjadi suatu peristiwa yang menggerakkan hukum untuk bekerja dalam rangka memberikan perlindungan terhadap antar pihak yang terhubung di dalam peristiwa hukum. Oleh sebab itu, dapat disimpulkan bahwa hanya peristiwa-peristiwa yang dicantumkan dalam hukum saja yang bisa menggerakkan hukum dan disebut sebagai peristiwa hukum.

Pada hukum dikenal dua macam peristiwa hukum ${ }^{3}$ : Pertama, peristiwa hukum yang bukan tindakan manusia, yakni kelahiran, kematian, dan daluwarsa; Kedua, peristiwa hukum yang merupakan tindakan manusia yang terbagi atas:

a. Perbuatan subjek hukum, yakni dapat dibedakan antara perbuatan hukum dan perbuatan lain yang bukan perbuatan hukum. Suatu perbuatan merupakan perbuatan hukum kalau perbuatan itu oleh hukum diberi akibat yang dikehendaki oleh yang bertindak. Apabila akibat hukum dari suatu perbuatan itu tidak dikehendaki oleh yang melakukannya atau salah satu dari yang melakukannya, maka perbuatan itu bukanlah suatu perbuatan hukum. Perbuatan hukum ada yang

\footnotetext{
${ }^{3}$ C.S.T. Kansil, Pengantar Ilmu Hukum dan Tata Hukum Indonesia, (Jakarta: Balai Pustaka, 1989) Hal 121
} 
bersifat satu arah (eenzijdig), misalnya pembuatan surat wasiat, pemberian hadiah (hibah), dan lain sebagainya; dan ada yang bersifat dua arah (tweezijdig), misalnya jual beli, sewa menyewa, dan lain sebagainya.

b. Peristiwa lain yang bukan perbuatan subjek hukum, yakni dapat dibedakan atas: Pertama, perbuatan yang akibatnya diatur oleh hukum, walaupun oleh hukum tidak perlu akibat tersebut dikehendaki oleh pihak yang melakukan perbuatan itu. Contohnya perbuatan memperhatikan (mengurus) kepentingan orang lain dengan tidak diminta oleh orang itu untuk memperhatikan kepentingannya (zaakwaarneming) yang diatur dalam Pasal 1354 KUHPerdata; Kedua, perbuatan yang bertentangan dengan hukum (onrechtmatige daad) yang diatur dalam Pasal 1365 KUHPerdata.

Hubungan anak angkat dengan orang tua angkatnya bukanlah hubungan sulbi, yang berarti anak kandung yang berasal dari sum-sum tulang sulbi dan tulang punggung. Sehingga kedudukan anak angkat hanyalah sebatas dalam hal hadhanah yang secara terminologis berarti memelihara dan mendidik seorang yang belum mumayyiz atau yang kehilangan kecerdasannya, karena mereka tidak bisa memenuhi keperluannya sendiri. ${ }^{4}$ Hibah termasuk bentuk tolong menolong, maka hukumnya adalah mandub $b^{5}$ yaitu dianjurkan. Hibah kepada siapa saja tidaklah dilarang asalkan rukun hibah dan syarat-syarat melakukan hibah telah terpenuhi, yaitu salah satunya adalah mengenai syarat harta yang dihibahkan ${ }^{6}$ :

1. Benda yang dihibahkan tersebut mestilah milik yang sempurna dari pihak penghibah.

Ini berarti bahwa hibah tidak sah apabila sesuatu yang dihibahkan itu bukanlah milik sempurna dari si penghibah.

2. Barang yang dihibahkan itu sudah ada dalam arti yang sesungguhnya ketika transaksi hibah dilaksanakan. Tidak sah menghibahkan sesuatu yang belum berwujud.

3. Objek yang dihibahkan itu mestilah sesuatu yang boleh dimiliki oleh agama. Tidak dibenarkan menghibahkan sesuatu yang tidak boleh dimiliki, seperti menghibahkan minuman yang dapat memabukkan.

4. Harta yang dihibahkan itu mestilah telah terpisah secara jelas dari harta milik penghibah.

Sehingga secara hukum tidaklah dilarang orang tua angkat menghibahkan hartanya kepada anak angkatnya, tetapi dengan memenuhi segala ketentuan hibah yang telah diatur dalam Hukum Islam. Maka, hibah yang diberikan kepada anak angkat dipersamakan seperti hibah kepada orang lain.

Penghibahan sebagai sebuah peristiwa hukum dapat dikenali sebab adanya ijab Kabul sebagai rukun hibah yang harus dipenuhi. Ijab Kabul dalam hibah menandakan adanya sebuah serah terima. Serah terima dalam hibah sama seperti serah terima dalam perkara jual beli. Apapun yang dinamakan sebagai serah terima dalam perkara jual beli maka dinamakan pula sebagai serah terima dalam masalah hibah. Sedang apa yang tidak dinamakan sebagai serah terima dalam perkara jual beli, tidak pula dinamakan serah terima dalam perkara hibah. ${ }^{7}$

Sebenarnya ajaran Islam tidak mensyaratkan agar dalam hibah disiapkan alat-alat bukti, seperti saksi, surat-surat otentik dan sebagainya. Tetapi banyak isyarat yang dari isyarat-isyarat itu dipahamkan bahwa sebaiknya dalam hibah itu ada alat-alat buktinya. Dengan adanya alatalat bukti itu akan timbul kepastian hukum baik bagi yang menghibahkan maupun bagi yang

${ }^{4}$ Abdul Azis Dahlan, Ensiklopedi Hukum Islam, (Jakarta: Ikhtiar Baru Van Hoepe, 1999), Hal 415

${ }^{5}$ Abdul Azis Muhammad Azzam, Fiqh Muamalah, ( Jakarta: Amzah, 2010), Hal 438

${ }^{6}$ Imam Syafi'I Abu Abdullah Muhammad bin Idris, Ringkasan Kitab Al Umm. Terjemahan Abdullah Muhammad bin Idris, (Jakarta: Pustaka Azzam, 2006), Hal 78.

Ibid, Hal 148 . 
menerima hibah. Apalagi jika kemudian hari terjadi perkara atau persoalan hibah itu, maka dengan adanya alat-alat bukti itu maka perkara atau persoalan itu mudah diselesaikan. Tentu saja yang diperlukan alat-alat bukti ialah hibah yang berhubungan dengan barang-barang yang tidak bergerak dan tahan lama, seperti tanah, kebun, rumah dan sebagainya. Islam menganjurkan hibah dilaksanakan dalam bentuk tertulis berdasarkan anjuran Al-Quran Surah Al-Baqarah (2) ayat 282 dan $283 .{ }^{8}$ Ayat ini juga dikenal sebagai ayat al-mudayanah (ayat utang piutang).

Sejalan dengan itu, penulisan hibah melalui Akta dapat dilihat pada KUHPerdata merujuk pada Pasal 1682 yang menyatakan bahwa: "Tiada suatu hibah, kecuali yang disebutkan dalam Pasal 1687 dapat ancaman batal, bila dilakukan selain dengan suatu akta Notaris, yang asli disimpan oleh Notaris itu".

Akibat hukum adalah segala akibat yang terjadi dari segala perbuatan hukum yang dilakukan oleh subyek hukum terhadap obyek hukum. Selain itu, akibat-akibat lainnya yang disebabkan oleh kejadian-kejadian tertentu yang secara hukum berkaitan dan telah ditentukan atau dianggap sebagai akibat hukum. ${ }^{9}$ Akibat hukum dapat dinyatakan sebagai suatu peristiwa yang ditimbulkan oleh karena suatu sebab, yaitu perbuatan yang dilakukan oleh subjek hukum, baik perbuatan yang sesuai dengan hukum, maupun perbuatan yang tidak sesuai dengan hukum.

Dalam hubungannya dengan surat keterangan hibah, maka dapat dipahami bahwa yang dimaksud dengan surat keterangan hibah merupakan surat pernyataan tentang pemberian hibah dari pemberi hibah kepada penerima hibah dengan saksi sebagai yang menyaksikan. Pada dasarnya setiap orang yang dapat menghibahkan (barang milik) sebagai penghibah kepada siapa saja yang ia kehendaki ketika penghibah dalam keadaan sehat.

Pada kasus hukum yang dikaji di sini, yakni tentang pemberian hibah atas harta bersama melalui surat keterangan hibah, oleh orangtua selaku pemberi hibah, dan penerima hibahnya adalah anak angkat (bukan ahli waris), diawali dengan menyelidiki yang dimaksud dengan surat keterangan hibah tersebut. Surat keterangan hibah dapat diartikan sebagai representasi atas peristiwa hibah yang dalam satu pemahaman dianggap menguatkan keberadaan pihak penerima hibah. Timbulnya surat keterangan hibah merupakan suatu peristiwa yang ditujukan agar kelak di kemudian hari ketika si pemberi hibah meninggal dunia, tidak ada anggota keluarga atau ahli waris yang mempersoalkannya karena itikad yang kurang baik atau tidak terpuji. Dalam hal, jika penerima hibah adalah anak kandung dari pemberi hibah maka surat keterangan hibah dapat dibatalkan atau hibahnya dapat dicabut.

Hibah dapat ditarik kembali berlaku bagi orang tua yang menghibahkan sesuatu kepada anaknya, dimaksudkan agar orang tua dalam memberikan hibah kepada anak-anaknya memperhatikan nilai-nilai keadilan.

Atas harta bersama, suami atau istri hanya dapat melakukan tindakan hukum terhadap harta tersebut dengan persetujuan dari pasangannya berdasarkan Pasal 36 ayat (1) UU Perkawinan, "Mengenai harta bersama, suami atau isteri dapat bertindak atas persetujuan kedua belah pihak." Dapat juga dilihat bunyi pasal 210 ayat (2) Kompilasi Hukum Islam (KHI), ketika benda yang akan dihibahkan itu adalah harta bersama, maka tindakan peralihan kepemilikan terhadap harta bersama sepatutnya dengan persetujuan pasangan, suami maupun istri. Tetapi ketika benda yang dihibahkan adalah milik isteri atau suami, maka tidak perlu persetujuan pasangan, namun dengan syarat sebanyak-banyak $1 / 3$ harta benda sebagaimana bunyi pasal 210

\footnotetext{
${ }^{8}$ Zainuddin Ali, Pelaksanaan Hukum Waris di Indonesia, (Jakarta: Sinar Grafika, 2012), Hal 139.

${ }^{9}$ Pipin Syarifin, Pengantar Ilmu Hukum, (Bandung: CV. Pustaka Setia, 1999) Hal 71.
} 
ayat (1). Tentang aturan harta bersama terdapat pada KHI pasal 1 huruf (f), selama dalam ikatan perkawinan baik harta yang diperoleh suami atau isteri disebut harta bersama, walaupun salah satunya tidak bekerja, seperti yang bekerja hanya suami, isteri hanya sebagai ibu rumah tangga, maka segala yang dihasilkan suami adalah harta bersama dengan isterinya, begitupula sebaliknya.

Berdasarkan Undang-undang Nomor 1 Tahun 1974 tentang Perkawinan pasal 36 ayat (1) dan Kompilasi Hukum Islam (KHI) pasal 92, dalam hal suami ingin menghibahkan harta bersama, maka suami harus mendapatkan izin dari istrinya, meskipun hibah tersebut dilakukan kepada anak angkat. Jika tidak ada izin atau persetujuan dari istrinya atas hibah tersebut, maka hibah tersebut dianggap tidak memenuhi syarat sebagai satu peristiwa hukum karena tidak adanya kewenangan dalam memberikan hibah tersebut. Hal ini juga tidak terpenuhinya syarat dari harta yang dihibahkan, yaitu harus merupakan milik mutlak penghibah, tanpa adanya hak orang lain terhadap harta benda yang dihibahkan.

Merujuk pada konsep syirkah abdan yang diatur dalam Kompilasi Hukum Islam, maka dapat dinyatakan bahwa akibat hukum dari surat keterangan hibah atas harta bersama yang meliputi tindakan pemberian (hadiah) oleh suami kepada anak angkat tanpa persetujuan dari istrinya, merupakan peristiwa hibah yang tidak memenuhi syarat hukum. Surat keterangan hibah dibuat tidak sesuai beberapa aturan yang ditentukan, yaitu melanggar Undang-undang Nomor 1 Tahun 1974 tentang Perkawinan Pasal 36 ayat (1) bahwasanya mengenai harta bersama suami dan istri dapat bertindak atas persetujuan kedua belah pihak. Surat keterangan hibah tersebut juga melanggar pasal 92 Kompilasi Hukum Islam (KHI) tentang suami atau istri tanpa persetujuan pihak lain tidak diperbolehkan menjual atau memindahkan harta bersama. Maka sebab itu, surat keterangan hibah tersebut tidak berkekuatan hukum, sehingga hibah menjadi batal.

\section{KESIMPULAN}

Dari seluruh rangkaian pemaparan diatas, maka dapat diambil kesimpulan sebagai berikut bahwa hibah kepada anak angkat dipersamakan seperti hibah kepada orang lain. Hibah kepada anak angkat tidaklah dapat ditarik kembali apabila rukun dan syarat hibah terpenuhi. Dalam hal harta bersama, selaras dengan syarat harta yang dihibahkan yaitu salah satunya haruslah milik mutlak penghibah. Pada harta bersama melekat pula hak istri terhadapnya, sehingga sesuai dengan pasal 92 Kompilasi Hukum Islam, maka istri memiliki hak yang sama dengan suami terhadap harta bersama, sehingga dalam mengalihkan dan memindahtangankannya haruslah berdasarkan persetujuan istri. Oleh karena itu surat keterangan hibah kepada anak angkat, yang objek hibahnya adalah merupakan harta bersama, yang dibuat tanpa persetujuan istri menyebabkan hibah menjadi batal dan surat keterangan hibah tidak berkekuatan hukum. Sebab surat keterangan hibah yang dibuat tanpa persetujuan istri tersebut merupakan representasi hibah yang terjadi tidak memenuhi syarat-syarat yang telah ditentukan dan telah melanggar ketentuan yang berlaku, yaitu Pasal 92 Kompilasi Hukum Islam (KHI) yang menghendaki adanya persetujuan kedua pihak suami istri dalam memindahkan harta bersama. Hal ini juga diatur dalam Undang-Undang Nomor 1 Tahun 1974 tentang Perkawinan pasal 36 ayat (1). 


\section{DAFTAR PUSTAKA}

Al Amruzi, Fahmi. 2014. Hukum Harta Kekayaan Perkawinan (Studi Komparatif Fiqh, KHI, Hukum Adat dan KUH Perdata). Yogyakarta: Aswanda Pressindo.

Al Amruzi, Fahmi. 2014. Rekonstruksi Wasiat Wajibah dalam Kompilasi Hukum Islam. Yogyakarta: Aswaja Pressindo.

Ali, Zainuddin. 2012 Pelaksanaan Hukum Waris di Indonesia. Jakarta: Sinar Grafika.

As'ad, Abd. Rasyid. 2010. Gono-Gini dalam Perspektif Hukum Islam. Jurnal Pengadilan Agama.

Azzam, Abdul Azis Muhammad. 2010. Fiqh Muamalah. Jakarta: Amzah

Besse Sugiswati. 2014. Konsepsi Harta Bersama dari Perspektif Hukum Islam, Kitab Undang-Undang Hukum Perdata, dan Hukum Adat.

Dahlan, Abdul Azis. 1999. Ensiklopedi Hukum Islam. Jakarta: Ikhtiar Baru Van Hoepe.

Elly Erawati dan Herlien Budiono. 2010. Penjelasan Hukum tentang Kebatalan Perjanjian. Jakarta: PT Gramedia.

Gosita, Arif. 1989. Masalah Perlindungan Anak-Edisi Pertama. Jakarta: Akademi Pressindo.

Haroen, Nasrun. 2007. Fiqh Muamalah (Cetakan kedua). Jakarta: Gaya Media Pratama.

Kansil, C.S.T. 1989. Pengantar Ilmu Hukum dan Tata Hukum Indonesia. Jakarta: Balai Pustaka.

Mardani. 2014. Hukum Kewarisan Islam di Indonesia. Jakarta: PT Raja Grafindo Perkasa.

Rahardjo, Satjipto. 1991. Ilmu Hukum. Bandung: Citra Aditya Bakti.

Sabiq, Sayyid dalam Abdul Manan. 2008. Aneka Masalah Hukum Perdata di Indonesia. Jakarta: Kencana.

Shomad, Abd. 2010. Hukum Islam: Penormaan Prinsip Syariah dalam Hukum Indonesia. Jakarta: Kencana Prenada Media Group.

Sudarsono, 1991. Hukum Waris dan Sistem Bilateral. Jakarta: PT Rineka Cipta.

Suparman, Eman. 2005. Hukum Waris Indonesia Dalam Perspektif Islam, Adat Dan BW. Bandung: Refika Aditama.

Syarifin, Pipin. 1999. Pengantar Ilmu Hukum. Bandung: CV. Pustaka Setia. Zaini, Muderis. 2002. Adopsi Suatu Tinjauan dari Tiga Sistem Hukum. Jakarta: Sinar Grafika. 